- 中井一人、澤田浩昭、神村共住、森勇介、佐々木孝友 (阪大院工)

- K.Nakai,H.Sawada,T.Kamimura,Y.Mori,T.Sasaki (Department of Electrical Engineering,Osaka University) はじめに 紫外レーザー光は、電子産業、医用など多くの分野でその応用が期待されている。近 年、従来の希ガスハライド系のエキシマレーザーの代替え光源として、固体レーザーと非線形光学結 晶による全固体紫外レーザー光源の開発が活発に行われている。非線形光学結晶CsLiB $\mathrm{O}_{10}$ (CLBO)結晶 は、紫外領域で優れた波長変換特性を持っことから Nd:YAGレーザーの4倍（266n m)，5倍 $(213 \mathrm{~nm})$ 高詮波の最も高効率な紫外光発生が可能である [1-3]。しかし、高出力紫外発生におい て、結晶のレーザー出射面での表面損甥が問題となっている。これらのレーザー損傷は、表面状態に 大きく依存し、とりわけ研磨加工における研磨不純物の付着が大きな原因であることがよく知られて いる [4]。我々は、CLBO結晶においてその表面状態の評価を行ったので報告する。

実験 表面粗さ0.5nm rms以下に光学研磨したCLBO結晶表面について、SIMSにより表面に付着して いると思われる研磨不純物の分析を行った。その結果、図1に示すように、光学研磨の際に用いた研ら 磨剤 $\mathrm{ZrO}_{2}$ が、結晶表面から深さ方向に60nmまで埋没していた。この埋没している研磨剤 $\mathrm{ZrO}$ の光学吸 収端は約300nm付近であることから、CLBO結晶による紫外光発生においてはその光学吸収がレーザー 損賃に影響を及ほすすことがわかる。表面レーザー損傷を低隇するには表面のこれらの光学吸収の要因 をなくすことが重要である。

まとめ 研磨加工後のCLBO表面において、研磨片が結晶表面から60nmまで埋没していることがわ かった。CLBO結晶の高出力紫外光発生には研磨剂の除去が必要と考えられる。

参考文献 [1] Y.K.Yap,et.al.,Optics Lett.21(1996)1348., [2] U.Stamm.et,al.,in Technical Digest of Advanced Solid-State Laser 1997., [3] Y.K.Yap.et,al..Optics Lett..23(1998)1016, [4] W.H.Lowdermilk and D.Milam: IEEE J. Quantum Electron.17(1981)1888.

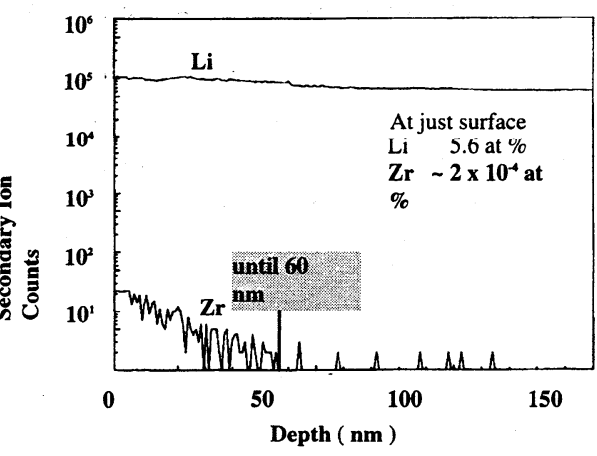

図 1.CLBO結晶内部の研磨剤の深さ分布

\title{
$28 \mathrm{a} \mathrm{V} 2$
}

Crystal Growth of GdYCOB Crystal for UV Generation

阪大院工 ○山田逸成、古屋博之、村瀬幸紀、中尾日六士、伊賀大介、山菩正隆、吉村政志、森勇介、佐々木孝友

Faculty of Eng., Osaka Univ., I. Yamada, H. Furuya, Y. Murase, H. Nakao, D. Iga, M. Yamasaki, M. Yoshimura, Y. Mori and T. Sasaki

mori@pwr.eng.osaka-u.ac.jp

はじめに 希土類・カルシウム・オキシボレート結晶は大きな非線形光学性、高い機械的安定性などといった特徵を有する優れた結晶である。過 去に報告されている結晶として GdCOB、YCOB があり、YCOB 結晶は GdCOB 結晶より大きな複屈折率を持つため、Nd:YAGレーザの第 3 高調波発 生 $(1064 \mathrm{~nm}+532 \mathrm{~nm} \rightarrow 355 \mathrm{~nm})$ が可能である。我々はこれまでこの 2 つの結晶が固溶した $\mathrm{Gd}_{\mathrm{x}} \mathrm{Y}_{1-\mathrm{x}} \mathrm{Ca}_{4} \mathrm{O}\left(\mathrm{BO}_{3}\right)_{3} に よ っ て$ 複屈折の制御が可能であることを 見いだした。そこで今回、複屈折率を任意に変化させることで、Nd:YAGレーザの第 3 高調波発生に適した組成での結晶の育成、波長変換特性の評 価を行ったので報告する。

実験と結果 高周波誘導加熱型融液引き上げ法(Cz 法)を用いて、様々な組成で b(y)軸方向に引き上げ た $\mathrm{Gd}_{\mathrm{x}} \mathrm{Y}_{1-\mathrm{x}} \mathrm{Ca}_{4} \mathrm{O}\left(\mathrm{BO}_{3}\right)_{3}$ 結晶を $\mathrm{y}$ 面または位相整合方向にカット、研磨し、Nd:YAG レーザの第 3 高調波発 生実験を行った。Gdの増加とともに複屈折が小さくなり、位相整合角が $\mathrm{y}$ 軸方向にシフトし、最適な $\mathrm{x}$ の值で最も効率よく波長変換が可能なノンクリティカル位相整合を取ることがわかった。これにより、 角度許容幅が広く、ウォークオフ角のない波長変換素子であることがいえる。そこで、ほほ同じ長さの $\mathrm{x}$ $=0.24$ の結晶と、YCOB 結晶を用いて、Nd:YAG レーザの第 3 高調波出力特性の比較を行ったところ、入 カパワーが $97 \mathrm{~mW} に$ 対し、YCOB 結晶の約 4 倍の出力が得られることを確認できた。（図 1 ) これは、ウ オークオフ角が小さくなったために変換効率が向上したものと考えられる。

まとめ YCOB 結晶の希土類サイトを Gd で部分置換することにより、複屈折を制御し、ウォークオフ 角のない波長変換素子を作製することができた。これにより、Nd:YAG レーザの第 3 高調波発生効率が

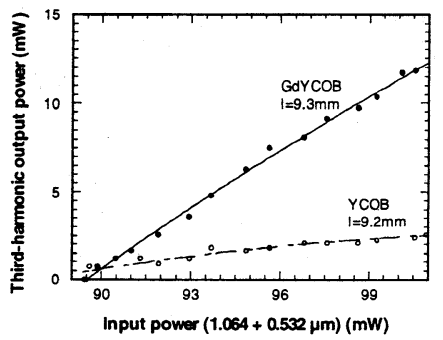

図 1

大幅に向上した。 
28a V 3

非線形光学結晶KAB結晶の育成と評価

Growth and characterization of nonlinear optical crystal, KAB 大阪大学大学院工学研究科

○東山折治, 胡章貴, 吉村政志, 森勇介, 佐々木孝友

Faculty of Eng, Osaka Univ. Tetsuji Higashiyama, Hu Zhang-Gui, Masashi Yoshimura, Yusuke Mori, Takatomo Sasaki

1.はじめに 近年、全固体紫外線レーザー光源が注目されており、 $\beta-\mathrm{BaB}_{2} \mathrm{O}_{4} や \mathrm{CsLiB} \mathrm{O}_{10}$ などの紫外光発生用非線形光学結晶の研究が進められて いる。特にNd:YAGレーザーの5倍高調波の発生に、優れた非線形光学結晶の開発が望まれている。このような状況下で、我々は $\mathrm{K}_{2} \mathrm{Al} \mathrm{l}_{2} \mathrm{~B}_{2} \mathrm{O}_{7}(\mathrm{KAB})$ の育成 とその評価を行ったので報告する。

2. KAB結晶の育成と評価 カリウム、アルミニウム、ホウ酸の混合物を融解、徐冷 することによりKAB微結晶を得た。結晶構造解析の結果、三方晶で、 $\mathrm{Sr}_{2} \mathrm{Be}_{2} \mathrm{~B}_{2} \mathrm{O}_{7}(\mathrm{SBBO})$ のS $\mathrm{SK}$ K゙BeをAlで、電荷の違いに係わらず、置換したものであ ることが分かった。 $\mathrm{KAB}$ は $1100^{\circ} \mathrm{C}$ 付近で分解するため, 原料として $\mathrm{K}_{2} \mathrm{CO}_{3}, \mathrm{Al}_{2} \mathrm{O}_{3}, \mathrm{~B}_{2} \mathrm{O}_{3}$ を様々な組成で混合したフラックス法で徐冷により育成を行った 結果、11日間で $6 \times 6 \times 1 \mathrm{~mm}^{3}$ の単結晶が得られた。複屈折率を油浸法で測定した結果 0.07 程度であり、深紫外光の発生に適した大きさといえる。また層状構造を有するた め、C軸方向に厚みのある結晶が得にくくなっているが、結晶構造から判断すると、 SBBOより育成は容易であると思われる。しかし育成溶液は粘度が高く、高温では蒸 発するなど良質な結晶の㕕成は困難であった。そこで我々は溶液組成を変化させるこ とにより育成温度、溶液粘度を降下させ育成を行った。現在は育成条件の最適化およ びその他特性の測定を行っている。この詳細は当日報告する。

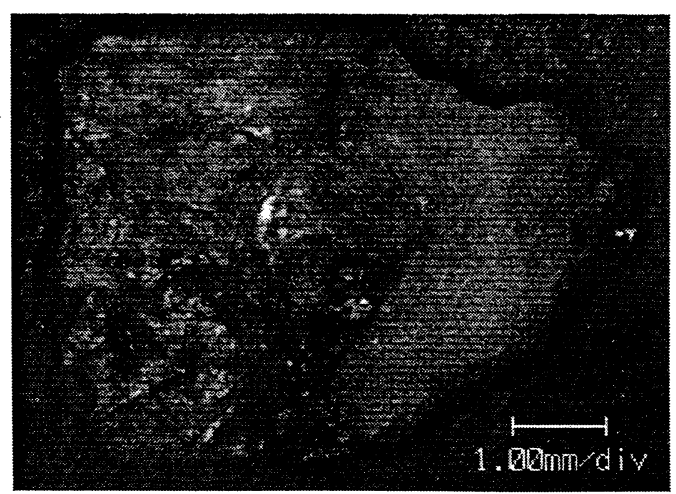

$28 \mathrm{a} V 4$

\section{$\mathrm{CBO}$ 結晶の育成と評価}

Growth and characterization of $\mathrm{CBO}$ single crystal

影林由郎A,B、森勇介B、佐々木孝友 $B$

A (株) ウシオ総合技術研究所、B 大阪大学大学院工学研究科

Yoshio Kagebayashi, Yusuke Mori and Takatomo Sasaki

A:Ushio Research Institute of Technology Inc., B:Osaka University

はじめに 次世代リソグラフィ光源として発振波長193nmのArFエキシマレーザーが検討されている。しかしエキシマレーザーは、寿命が短 い、メンテナンスコストが高いといった欠点を有しており、これらの問題を克服した全固体レーザーの実現が期待されている。193nmを和周波 発生する非線形光学結晶の条件として、吸収端が短いこと、実効非線形定数が大きいことが重要になる。CsB3 $\mathrm{O}_{5}$ 結晶は吸収端が $167 \mathrm{~nm}$ 紫外 域において実効非線形定数が大きいので、193nm和周波発生用結晶として期待できる。しかし、現在までCBO結晶の光学特性や非線形特性につ いての報告はあるが、結晶育成に関する具体的な報告がない。今回、大型のCBO単結晶育成に成功し、得られた結晶の光学特性として屈折率分 布と分光透過率を評価したので報告する。

実験及び結果 結晶育成にはセルフフラックスを 用いたカイロポーラス法とした。温度降下速度を $0.1^{\circ} \mathrm{C} /$ dayとし、シード回転数を变化させて結晶 育成を行った。シード回転数 $25 \mathrm{rpm}$ で育成した結 晶は白濁したが、シード回転数を60rpmのとき、 インクルージョンやクラックのない単結晶が育成 できた。図 1 は㕕成した結晶の一例を示す。得ら れた結晶の最大の大きさは $\mathrm{axbxc}=45 \mathrm{x} 41 \mathrm{x} 44 \mathrm{~mm}^{3}$ だった。得られた結晶を $8 \times 7 \times 5 \mathrm{~mm}^{2}$ にカットし、 屈折率分布をフィソー干涉計によって測定した。 その結果、 $1 \times 10^{-5}$ 程度であり、実用上問題がない ことがわかった。和周波を発生する際、 $2 \mu \mathrm{m}$ 域 から吸収端付近の透過率を明らかにする必要があ る。図 2 はCBO結晶の分光透過率を示す。193nm 付近に吸収がなく、熱の発生も少ない之考えられ る。深紫外光発生用として使用に耐えうる良質な

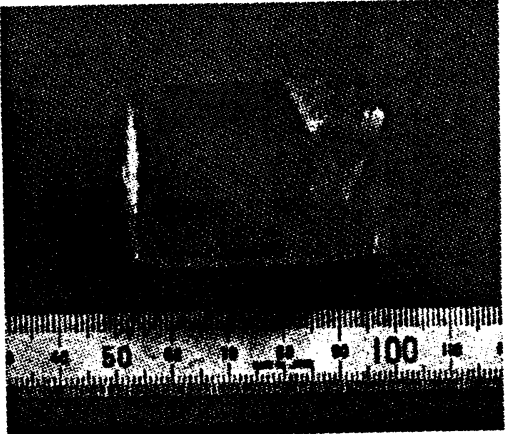

圆1 as-grown CBOH渵

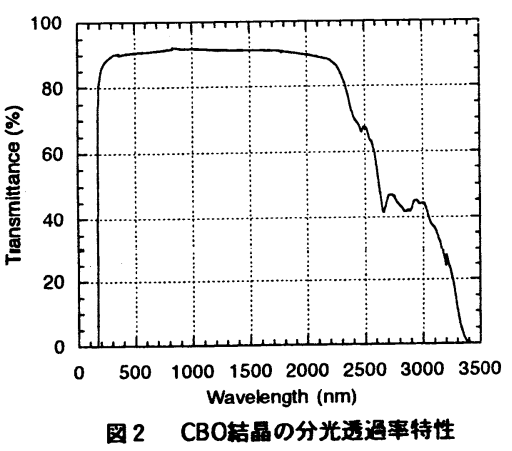

园 2 CBO結晶の分光这通事特性 結晶が育成できた。 
出来恭一, 佐久間純, 横田利夫, 大迫 康, 吉野雅也, 堀口 昌宏

( (株) ウシオ総合技政研究所)

K. Deki, J. Sakuma, T. Yokota, Y. Ohsako, M. Yoshino, M.Horiguchi (Ushio Research Institute of Technology Inc.)

公表されているCLBOのセルマイヤー方程式 [1], |2|を用いるとNd:YAGレーザの基本波波長 $(1064.21 \mathrm{~nm})$ と $236.4 \mathrm{~nm}$ 光との和周波混合に よっておよそ $\theta=76^{\circ}$ で位相整合し， ArFレ 一ザと同一の波長の $193.4 \mathrm{~nm}$ 光が発生できる と計算されるにもかかわらず，上記 2 波長の 組合せでは，図1に示すように室温で全く位 相整合しないことを実験的に確認した。実験 にはTSSG法で育成されたを用いた.Nd:YAG レーザの基本波波長を固定し，もう一方 の波長を変えた実験によって室温 $\left(23^{\circ}\right)$ で は1064.21nmと $238.8 \mathrm{~nm}$ とのSFMにより $195.0 \mathrm{~nm}$ 発生でnon-critical 位相整合すること がわかった. また, CLBOの結晶温度を変えた 実験では, NCPMによってArFエキシマーレー ザ波長に対応する193.39nm光を発生するには,
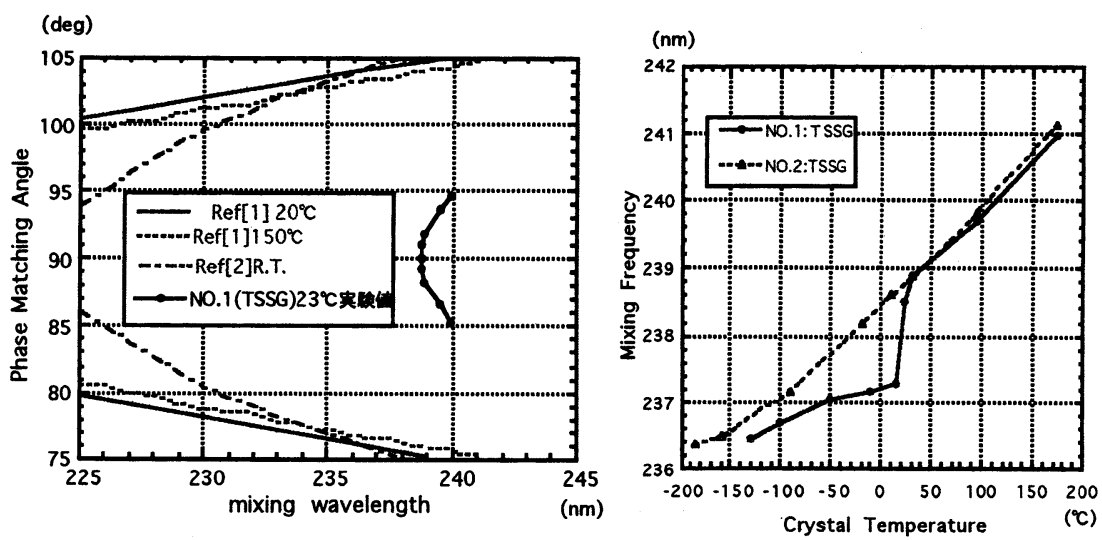
CLBO温度を約 $-185^{\circ} \mathrm{C} に$ 冷却する必要があること

を見出した（図2）。 また，上記公表されたセルマイヤー方程式と dn/dTから計算されたtuning rate $\mathrm{d} \lambda / \mathrm{dT}$ は実験的に得られたtuning rateと 大きく異なった. さらに, 結晶温度 $0^{\circ} \mathrm{C}$ 付近でtuning rateが大きく変化する試料も存在することが実験的に確認できたが, 現在，この原因はあ きらかではない.

(文献) |1|N.Umemura and K.Kato;Appl. Opt. vol.36, No.27(1997)p.6794-6796 [2]Y.Mori et al. ;Appl. Phys. Lett. vol. 67, No.13, (1995)p.1818-1820 
ZnS-based light-emitting diodes with $340 \mathrm{~nm}$ ultraviolet luminescence

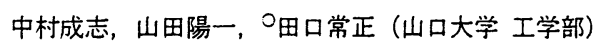

Seiji NAKAMURA, Yoichi YAMADA, and Tsunemasa TAGUCHI (Faculty of Engineering, Yamaguchi University)

1.はじめに

II -VI族化合物半導体である硫化要鉛 $(\mathrm{ZnS})$ は、直接遷移型のバンド構造を有し、室温でのバン ドギャッブが $3.73 \mathrm{eV}$ と ZnSe、GaN よりも大きいことから、ZnSe 系、GaN 系では実現できない波 長領域での発光・受光デバイス（特に紫外(UV)発光ダイオード(LED), レーザダイオード）の材料 として有望である。また、励起子結合エネルギーが約 $40 \mathrm{meV}$ とワイドギャップ半導体の中でも特 に大きな值を有することから、励起子効果を利用した発光デバイスの実現が期待できる。そこで 紫外発光素子への応用について発光ダイオード(LED)を作製し検討を行った。

2. 実験方法

ZnS LED は、ジメチル亜鉛 $(\mathrm{DMZn}) 、$ 硫化水素 $\left(\mathrm{H}_{2} \mathrm{~S}\right) 、 \exists ウ$ 化エチル $\left(\mathrm{C}_{2} \mathrm{H}_{5} \mathrm{I}\right)$ 及びターシャリブチ ルアミン $\left(\mathrm{t}-\mathrm{BuNH}_{2}\right)$ をそれぞれ使用して $(100)$ 面 $\mathrm{n}^{+}$-GaAs 基板上に減圧 MOCVD 法により作製した。 $\mathrm{S}$ 層として電子港度が約 $1 \times 10^{19} \mathrm{~cm}^{-3}$ である $\mathrm{ZnS}: I$ 膜を $4 \mu \mathrm{m}$ 、その上に $\pi$ 層として高抵抗 $\mathrm{p}$ 型 $\mathrm{ZnS}: \mathrm{N}$ 膜を 1000 Å成長させた。 $\mathrm{n}^{+}$-GaAs 基板のオーミック電極として Au-Ge、 $\pi$ 層のショットキー 電極として $500 \AA$ 程度の $\mathrm{Au}$ 雨極を蒸着した。

3. 結果と考察

右図に、作製した M $\pi \mathrm{S}$ 構造 LED に逆バイアス $13 \mathrm{~V}$ 印加したときに得られた室温における EL

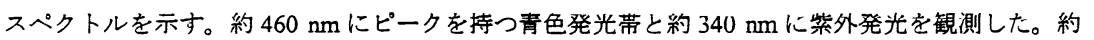
$460 \mathrm{~nm}$ にピークを持つ青色発光帯の起源は、ZnS:Iに見られる SA 発光の SA センターにトラッブ されている正孔と自由電子との再結合によるものであると考えられる。一方、約 $340 \mathrm{~nm}$ に見られ る紫外発光は、そのピーク波長位置から、室温で観測される自由励起子発光ではないかと考えら

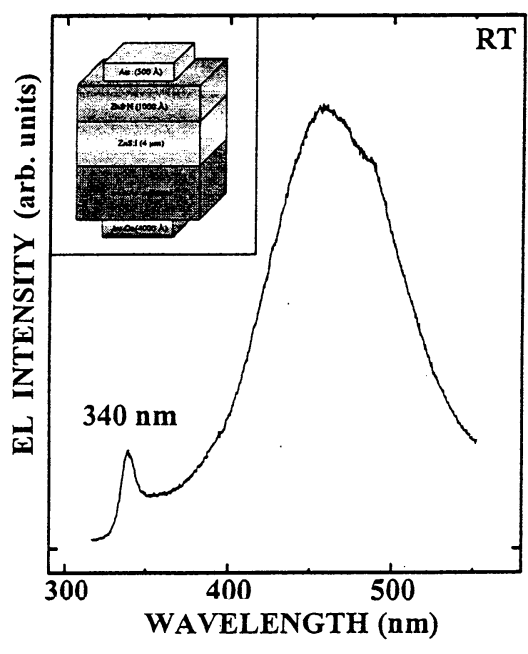

$M \pi S$ 構造LEDの概略図と発光スペクトル

れる。ZnS を用いた LED で紫外発光が室温において観測されたのは本研究が初めてである。この結果から、紫外発光素子材料として ZnS が非常に有 用であることが示され、最も単純な pn 接合 LED 構造で励起子発光を利用した紫外発光 LED が作製可能であると考えられる。

\section{9aVIII3 CdZnS 量子井戸の励起子分子による紫外誘導放出}

Ultraviolet stimulated emission due to radiative recombination process of biexcitons in $\mathrm{CdZnS}$ quantum

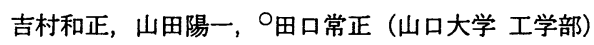

Kazumasa YOSHIMURA, Yoichi YAMADA, and Tsunemasa TAGUCHI (Faculty of Engineering, Yamaguchi University)

はじめに III-V 族化合物半導体の GaN を用いて、青から紫外の短波長領域で動作する半導体レーザの研究・開発が精力的に行われ、実用化が間近とな っている。一方、ZnSe といった II-VI 族化合物半導体をベースとした半導体レーザは III-V 族半導体レーザに先んじて室温レーザ発振を達成したものの、 結晶中に存在する欠宿等のためにさらなる長寿命化に大きなポテンシャルを有している。しかしながら、近年 II-VI 族半導体レーザにおけるレーザ発振への励起子の奇与が大きな注目を集めている。この励起子のレーザ発振への 寄与は、励起子の有する巨大振動子効果により、半導体レーザの量子効率の向上や寿命の增大など、従来の半導 体レーザと比較して格段に優れた性能を有するデバイスの作製を可能にすると期待されている。

本研究で用いた $\mathrm{ZnS}$ (硫化亜鉛) は、室温において約 $3.73 \mathrm{eV}$ という大きなバンドギャップエネルギーを有し、 $36 \mathrm{meV}$ という大きな励起子結合エネルギー（室温の熱エネルギー : 約 $25 \mathrm{meV}$ ) を有しているため、紫外域で動作 する室温励起子発光デバイスへの利用が期待できる材料であり、かつ、高密度励起下での励起子物性の研究にも 適した材料であるといえる。

実験の方法 $\mathrm{Cd}_{\mathrm{X}} \mathrm{Zn}_{1-\mathrm{x}} \mathrm{S}-\mathrm{ZnS}$ 多重量子井戸構造の作製は減圧 MOCVD 法により GaAs 基板上に行った。その後、作

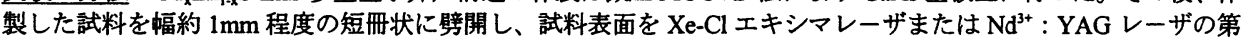
二高調波励起の色素レーザの第二高調波を用いて励起し、試料端面から観測された発光の励起パワー密度依存性 および温度依存性の測定を行った。

実験結果と考察 図 1 は、Cdの組成比が 0.2 でそれぞれ（i） $5.7 \mathrm{~nm}$ 、(ii) $3.1 \mathrm{~nm}$ および（iii） $2.3 \mathrm{~nm}$ の井戸幅

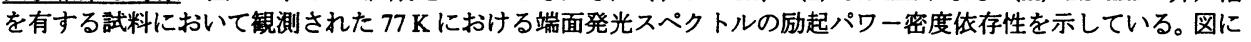
見られるように、いずれの試料においても弱励起下では $\mathrm{n}=1$ 重い正孔の励起子による発光 $(\mathrm{X})$ が観測される。 その後、励起パワー密度の增大に伴い励起子分子の発光 $(\mathrm{XX})$ が観測され、さらなる励起パワーの增大により誘 導放出（SE）がその励起子分子の発光位圈で生じている。このことから、これらの試料においては励起子分子に よる誘導放出が生じているものと考えられる。

講演では、誘導放出光の構造依存性および温度依存性の測定結果についての報告を行い、唀導放出機構の変化 および柴外領域で動作する励起子半導体レーザの実現についての考察を行う。

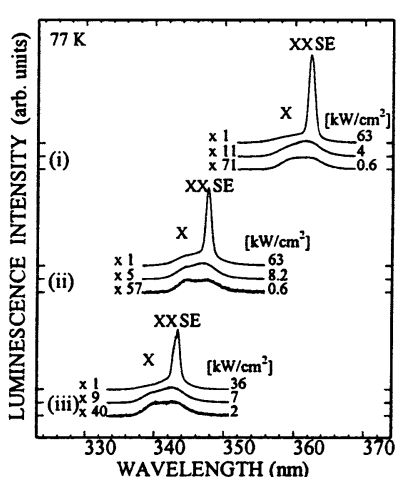

図 1. $\mathrm{Cd}_{0.2} \mathrm{Zn}_{0.8} \mathrm{~S}-\mathrm{ZnS}$ 多重量子井戸構造 における端面発光スペクトルの 励起パワー密度依存性. 井戸幅は それぞれ（i） $5.7 \mathrm{nm、（ii）} 3.1 \mathrm{~nm}$ 、 (iii) $2.3 \mathrm{~nm}$. 
[はじめに］近年、InGaN 三元混晶を活性層とする紫外 LED が開発され、生物医学的な領域などさまざま な分野での応用が期待されている。しかしながら、現在实用化されているInGaN 紫外 LED は、すでに実用 化されている InGaN 青色、緑色 LED と比较して外部量子効率が柍めて低いことが指摘されている。従って、 活性層に注入されたキャリアの発光再結合過程を解明することは、高効率紫外 LED の実現に不可欠である と考えられる。

[実験と結果] 今回、我々は InGaN 紫外 LED における発光スペクトルの温度依存性及び磁場特性に関する 実験を行い、発光再結合過程の考察を行った。図 1 にInGaN UV LED における発光ピークエネルギーの温度依存性測定結果を示す。発光 ピークエネルギーは温度の上昇に伴い低エネルギー側ヘシフトし ており、GaNにおけるバンドギャップエネルギーの温度変化に関す る理論式でフィッティングできる。また、InGaN 紫外 LED の発光 スペクトルの磁場特性に関する実験を行った結果を図 2 に示す。測 定に用いた磁場装置は、オックスフォード社製の Spectromag 4000 で超伝導磁石を利用して最大 9T の磁場を発生させることが出来る。 InGaN 活性層からの発光は $3.4 \mathrm{eV}$ 付近に位置し、磁場の増加に伴い 発光ピーク位置は高エネルギー側ヘシフトしており、磁場によるエ ネルギーシフトはランダウシフトの理論式とほぼ一致した。また、 理論的に求めた励起子の反磁性シフトと実験結果との比較を行う ことにより、活性層に注入されたキャリアの発光再結合課程に関す るさらなる考察を行った。これらの実験結果より、InGaN 紫外 LED の活性单における発光再結合においては In の組成不均一の影響が 弱いと考えられ、キャリアの局在の影響も小さいと考えられる。 [謝辞] LED を御提供頂いた日严化学工業の中河揫典氏に感謝しま

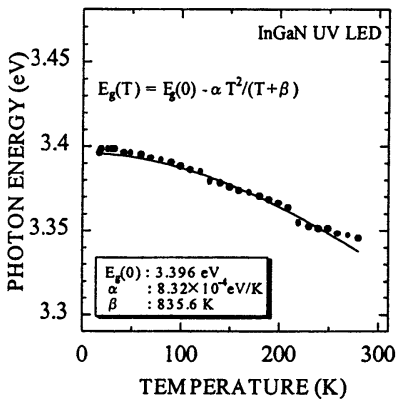

図 1. 発光ピークエネルギーの 温度依存性

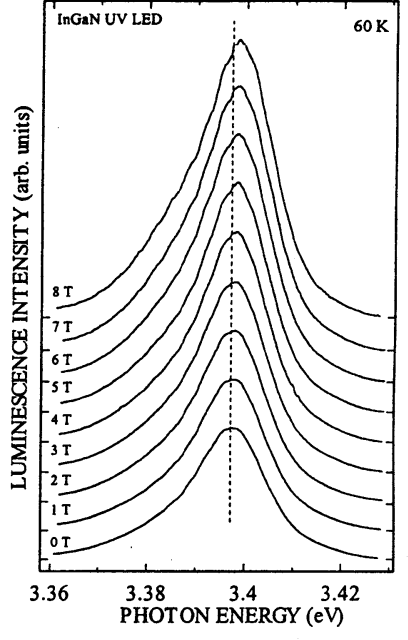

図 2. PL スペクトルの磁場依存性 す。

\section{1.はじめに}

GaN 系面発光レーザーの実現には高反射率を有する共振器ミラーの形成が必要である。我々 は GaN/AIGaN 交互多層膜 30 pair からなる分布型ブラッグ反射鏡(distributed Bragg reflector : DBR) を作製し、高反射率を得た。しかし、格子定数差や熱膨張係数差により多くのクラックが発生 し、高反射率を示すのは 2 インチ基板の一部分であった。そこでクラックの発生を抑制するた め、AlGaN/GaN からなる歪超格子(strained layer superlattices : SLSs)構造を導入したところ、基板 の中心部分でクラックの発生が抑制され反射率が向上したので報告する。

\section{2. 実験方法}

常圧 MOCVD 法により 2 種類の DBR 構造を作製した。一方は、サファイア(0001)基板上に低 温 $\mathrm{GaN}$ 層を $30 \mathrm{~nm}$ 成長した後, $1080^{\circ} \mathrm{C} て ゙ \mathrm{GaN}$ を $2 \mu \mathrm{m}, 800^{\circ} \mathrm{C} て ゙ ~ \mathrm{Ga}_{0} \mathrm{In}_{0,1} \mathrm{~N}$ を $0.1 \mu \mathrm{m}$ 成長し、1080 で GaN $/ \mathrm{Al}_{0.27} \mathrm{Ga}_{0.73} \mathrm{~N}$ からなる $\mathrm{DBR}$ を 30 pair 形成した。もう一方は、DBR の形成の前に $1080^{\circ} \mathrm{C}$ で $\mathrm{Al}_{027} \mathrm{Ga}_{073} \mathrm{~N} / \mathrm{GaN}$ からなる SLSs を 100 周期形成した。これらは室温で反射率の評価を行い、 DBR の膜厚、急峻性の評価には走査型電子顕微鏡(scanning electron microscope : SEM)とスパッタ リングオージェ電子分光法(sputtering auger electron spectroscopy)を用いた。

\section{実験結果およひ考察}

室温で反射率の測定を行ったところ、SLSs 構造を用いなかったものは $416 \mathrm{~nm}$ の波長で 93\% の反射率を示したが、SLSs 構造を導入したものは $409 \mathrm{~nm}$ で 98\%の反射率を示した（図 1)。こ こで、DBR の設計中心波長は $410 \mathrm{~nm}$ である。DBRのそれぞれの層の膜厚を断面 SEM より求め たところ、SLSs 構造を導入したものは導入しなかったものと比べてそれぞれの膜厚が薄くなっ ていることがわかった。このため、SLSs 構造を用いた反射鏡の反射率Uピーク波長が SLSs 構 造を用いなかったものより短波長側に現れたと考えられる。また、どちらの構造も DBR の各層 の膜厚にはばらつきがあった。このばらつきは反射率の低下の原因になっていると考えられる。 また、SLSs 構造を導入することによってサンブルの中心部分でクラックの数が大幅に減少した。 このため、SLSs 構造を用いたものの反射率が高くなったと考えられる。

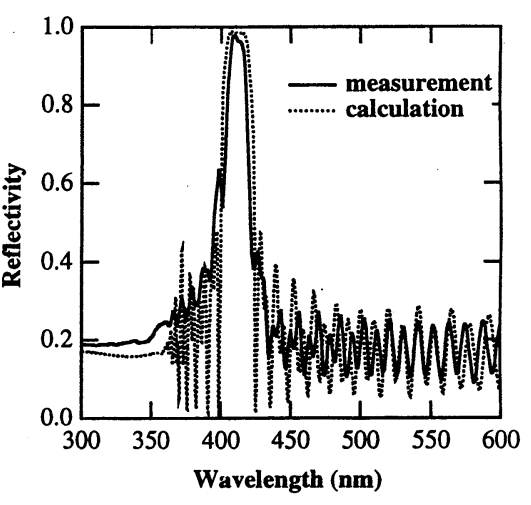

图1 GaN/Alo.27Ga0.73N 30 pairs DBR

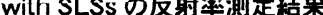


Improvement of wavelength conversion efficiency using four-wave mixing in a semiconductor laser

○下山峰史，鈋塚治彦，Brent E. Little，松田学，小滝裕二，石川浩（富士通研究所）

SIMOYAMA Takasi, KUWATSUKA Haruhiko, Brent E. Little, MATSUDA Manabu, KOTAKI Yuji, and ISHIKAWA Hiroshi

(Fujitsu Laboratories Ltd.)

背景 利得を持つ半導体導波路中の非縮退四光波混合は、高効率・広带域な波長変換を実現する有力な手段

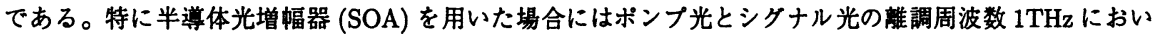
$て+5 \mathrm{~dB}$ という高い変換剂率が観測されている $[1]$ 。我々は以前より位相シフト型の DFB レーザで自身の発 振光をポンプ光として用いる波長変換素子を提案してきた $[2] 。 S O A$ と比較すると、外部の光源を必要とせ ず単一素子動作するという利点を持つ反面、変換効率に寄与する線形利得が発振閵值に固定されるため効 率の改善には工夫が必要となる。SOAの場合、共振長の增加が (ポンプとシグナルとの) 相互作用長と線形 利得とを同時に增加させ、高効率化に直結する。参考文献 [1] では $1.5 \mathrm{~mm}$ の長共振器を用いている。レー ザの場合、長共振器化は利得の低下につながるため効率に有利な構造が明確ではなかった。

実験結果と考察 $\lambda / 4$ 位相シフト DFBレーザ内のポンブ光強度分布と利得の飽和特性を考慮した変換効率の 計算を行った結果、導波光と回折格子との結合係数 $\kappa$ を(発振閾值を上げる為)十分に小さく $\left(\sim 10 \mathrm{~cm}^{-1}\right)$ した構造では共振器長を増加させることが有利に作用し、特に変換光強度/雑音比 $(\mathrm{S} / \mathrm{N})$ に関して大幅な改 善が期待されることが分かった。実際に $\kappa=12 \mathrm{~cm}^{-1}$ の導波路構造を持ち共掁器長 $550 \sim 1300 \mu m$ の DFB レーザを作成して実験を行なったところ $550 \mu m$ から $1300 \mu m$ への変化に伴い約 $14 \mathrm{~dB}$ という S/N の改善 が観測された (図 1)。これは計算による予想值 $12 \mathrm{~dB}$ とよい一致を示している。

さらなる変換効率の改善には素子の線形利得の增加が不可欠である。我々はレーザ発振の安定性を保ち つつ線形利得を增大させるため、DFB レーザに SOA を集皘化した構造を提案した [3]。実際に DFB 部 $300 \mu \mathrm{m} / \mathrm{SOA}$ 部 $500 \mu \mathrm{m}$ の素子を作成し実験を行なった結果、離調 $300 \mathrm{GHz}$ 以内では $0 \mathrm{~dB}$ 以上、離調 $1 \mathrm{THz}$ においても-5dB の効率が観測された (図 2)。単一素子動作で損失無しの変換を観測したのはこれが初めて である。

[1] F. Girardin, et al. IEEE. Photon. Technol. Lett., Vol. 9, pp. 746-748, 1997.

2 H. Kuwatsuka, et al. IEEE J. Quantum Electron., Vol. 33, pp. 2002-2010, 1997.

[3] B. E. Little, et al. IEEE Photon. Technol. Lett., Vol. 10, pp. 519-521, 1998.

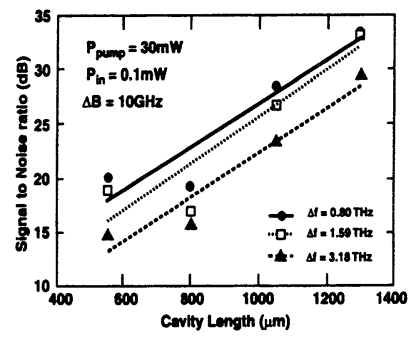

図 1 変换光強度/雜音比の共掁器長依存性

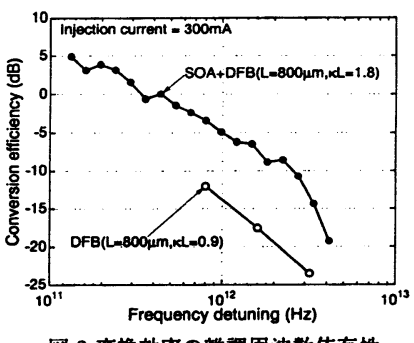

図 2 変换効率の讙調周波数依存性

29aVIII8ＤFB-LD 内の非縮退四光波混合を用いたサイドバンド注入同期

Side-band injection locking using cavity-enhanced highly non-degenerate four-wave mixing in DFB-LD

○後藤 了祐、西澤 典彦、後藤 俊夫、粕谷 英明”、森 正和”、山根 一雄” (名古屋大学、“愛知工業大学、“富士通(株))

${ }^{\circ}$ R.Goto, N.Nishizawa, T.Goto, H.Kasuya", M.Mori” and K.Yamane“ (Nagoya University, "Aichi Institute of Technology, "FFujitsu Limited.)

はじめに 現在、波長分割多重(WDM)システムにおける光源の波長制御は、各レーザを個別に温度制御する手法が一般的である。しかし、今後の更なる大 容量化に伴い、波長(チヤン初)間隔が狭くなると、より高精度な波長制御法を確立せねばならない。そこで我々は、DFB.LD 内での四光波混合(FWM)を 利用した注入同期によって、多波長光源の発振波長を一括して安定化する手法を提案する。

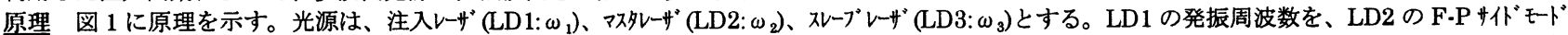
に一致させ、単方向注入する。その結果、2 $2 \omega_{2}-\omega_{1}$ のFWMが生成される。LD1 と FWM の周波数は、LD2 の F.P モードに一致しているため、共振 器内一の閉じこめが強く、比較的高効率の FWM 成分が得られる。この LD2 の出力光を、 $\omega_{2}$ より約 $1 F \cdot P$ モード間隔離れた LD3 に注入すれば、FWM 成分によって注入同期が起こり、LD3 の発振周波数 $\omega_{3}$ が、2 $\omega_{2}-\omega_{1}$ に咏される。

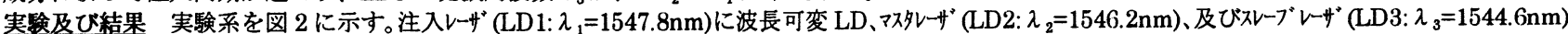
にDFB-LD を用いた。LD2 内で FWM を生成し、その出力光を LD 3 に注入した。Confocal F.P(FSR=2GHz)によって同期・非同期の確認をした後、

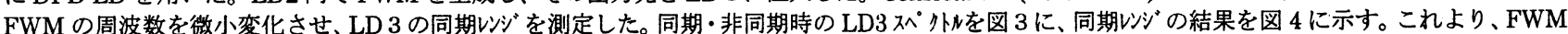
を用いた注入同期を行えば、発振周波数が $200 \mathrm{GHz}$ 程度離れた LD 間でも、発振スペ外を安定化できることが明らかになった。

4. まとめ DFB-LD 内の非縮退四光波混合を用いた忆゙ベンド注入同期を試み、発振ス゚外Nの安定化を確認した。同様の構成で、更に LD4、LD5 ‥ と縦続接続すれば、LD1 と LD2 のみの精密温度制御で、全光源の周波数安定化が可能となる。これは、WDM 光源の波長一括安定化に適用可能で ある。

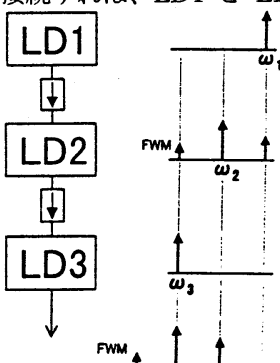

図1 原理

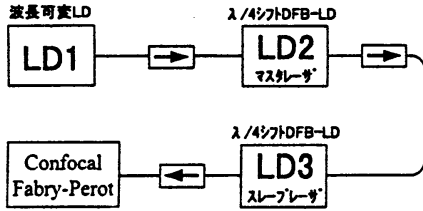

図2 実䄼系

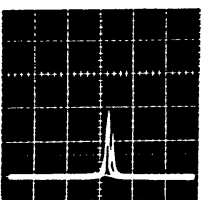

(a)非同期时

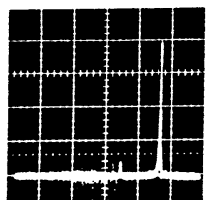

(b)同期时

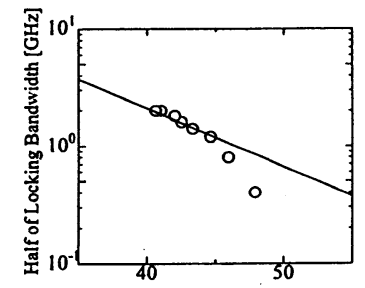

$\mathrm{P}_{\mathrm{SL}} / \mathrm{P}_{\mathrm{FWM}}[\mathrm{dB}]$

図4 同期

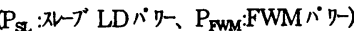


29aVIII9 高出力AlGaAsレーザーアレイの光出力特性

Light output characteristics of high power AlGaAs laser diode arrays

西川 祐司, ○瀧川 宏 (株式会社 富士通研究所)

Yuji Nishikawa, Hiroshi Takigawa (FUJITSU LABORATORIES LTD.)

固体レーザー励起用高出力半導体レーザーの一次元アレイ (レーザーバー) では, ジュール発 熱による出力飽和を㧕制することが重要であり，ジュール熱によるレーザーバーの温度上昇を考 虑した設計ツールが必要である。

我々は，AlGaAs系レーザーバーの設計シミュレー夕を開発し，実際にエピ層の構造を変える ことにより光閉じ込め係数と内部損失の異なるレーザーバーを試作して，その光出力特性をシミュ レータの算出結果と比較した。その結果, 光出力特性の実測值と算出結果は良い一致を示し, シ ミュレータの有効性が確認できたので報告する。

シミュレータでは，はじめにバンドを放物線近似して計算したゲインがキャリア分布と光強度 分布の重なりから計算される内部損失とミラー損失との和と一致する条件から閾値キャリア密度 を求めた。次に, このキャリア密度に対応したライフタイムから䦭值電流を計算し，キャリアの 量子井戸からのオーバーフローを考慮したスローブ効率から光出力特性を算出した。レーザーバー の電流注入による温度上昇を考虑するため, オージェ再結合[1]を考虑した各温度での光出力特 性を計算し，レーザーバーの温度上昇による出力低下を見積もった。

Fig. 1は, $0.8 \mu \mathrm{m}$ 帯のレーザーバーの光出力特性の実測值とシ

ミュレータによる計算値を表している。測定における最大注入電 流は，出力の熱的飽和が観測され始めた電流としている。これら $\mathrm{A} \sim \mathrm{C}$ の種類のレーザーバーは，いずれも幅 $1 \mathrm{~cm} て ゙ 70 \mu \mathrm{m}$ 幅のブ ロードストライプを66本パッキングしており，その光閉じ込め俰 数 $(\Gamma)$ と内部損失 $\left(\alpha_{\mathrm{i}}\right)$ はTable 1に示した通りである。また, 全てのレーザーバーはスタック可能な平板状の水冷式冷却器[2] にマウントして測定した。Fig. 1から明らかなように，実測值と 計算值は良い一致を示し，シミュレータの有効性が確認できた。

Table 1 Parameters of the laser bars.

\begin{tabular}{ccc}
\hline & $\alpha_{i}\left(\mathrm{~cm}^{-1}\right)$ & $\Gamma(\%)$ \\
\hline A & 3.5 & 3.3 \\
B & 4.0 & 5.0 \\
C & 4.8 & 4.5 \\
\hline
\end{tabular}

講演では，シミュレータの適用範囲や，光変換効率等の他の光出力特性についても報告する。 [1] N. Bewtra et al., IEEE JSTQE-1 (1995) 331.

[2] 瀧川, 西川, レーザー学会学術講演会第17回年次大会予稿, 23 aVI2 (1997) 34.

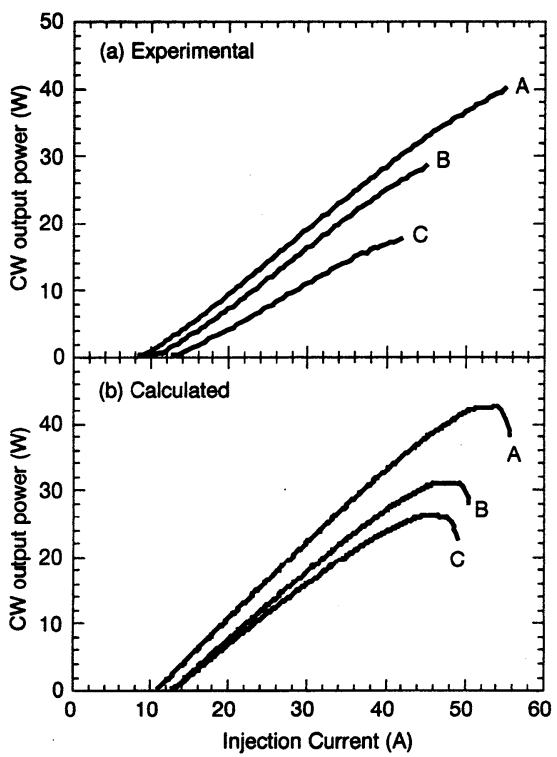

Fig. 1 Experimental and calculated light output power versus injection current.

\section{9aVIII10 反射光計測によるDFBーLDのデバイスパラメータ測定}

Derivation of DFB-LD Parameters by Using Reflected Light Measurement Method

○柾飼 拓男，西澤 典彦，後藤 俊夫，森 正和 A，山根一雄 B (名大工, A愛工大, B富士通)

'T.Ukai , N.Nishizawa, T.Goto, M.Mori A , K.Yamane B (Nagoya Univ. , A Aichi Inst.Tech. , B Fujitsu Ltd.)

\section{はじめに}

光通信の光源には、DFB-LDが実用化されているが、その特性はデバイスパラメータにより大き く変化する。そこで、これらのパラメータを測定することは、デバイスの評価, 特性改善, 応用にとって 非常に重要である。我々はこれまで、インコヒーレント光干涉計を用い，LD 端面からインコヒーレント 光を注入し、その反射光の空間的な分布から LD の反射率と内部利得を測定した[1]。更にその結果 を用いて、LDにコヒーレント光を注入した場合の反射光分布についての計算值と実験値との比較か ら、結合係数とブラッグ波長を導出した[2]。今回は更に、別のDFB-LDについてパラメータの導出 を試み、測定結果の比較・検討を行ったので報告する。

\section{実験方法}

これまでと同様にして、まずインコヒーレント干涉計(図 1)を用いて実験を行った。LD にインコヒー レント光を注入し、その反射光と参照光との干涉信号を測定した。入射光の中心波長が $1557.5 \mathrm{~nm}$ の 時に、参照光の光路長を变化させた時の LD での反射光の分布を図 2 に示す。これらの結果から LD の共振器長を決定し、参照光の光路長を LD 内を一往復と二往復する長さに固定し、干涉信号の波 長依存性を測定した。その波長依存性から LD の反射率 R 及び内部利得 $\alpha \mathrm{L}$ を求めた。更にその 結果を用いて、LD にコヒーレント光を注入した時の反射光分布の波長俅存性について、計算值と実 験值を比較することにより、結合係数 $\kappa$ ，ブラッグ波長 $\lambda_{\mathrm{B}}$ を求めた。今回は、異なる LD について得 られたパラメータの比較・検討を行う予定である。

参考文献

[1]松井他, 信学会全国大会春, C-4-68, 1997

[2] 鴊飼他, 信学会全国大会春, C-4-26, 1998

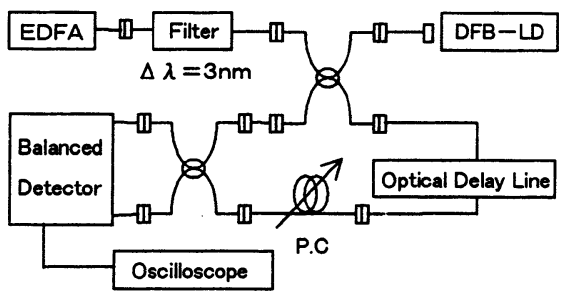

図 1 インコヒーレント干涉計

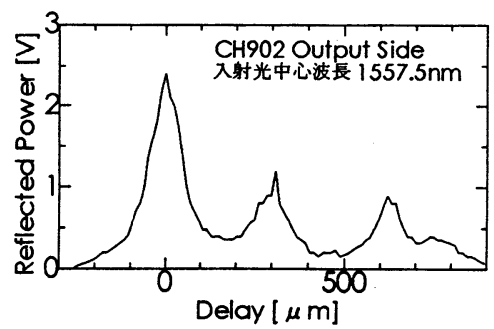

図2 反射光パワーの光路差依存性 


\begin{abstract}
Introduction : GaAs-based lasers are currently being investigated as the light source in opto-electronic integrated circuits fabricated on Si substrate. However, the large crystal lattice mismatch (4\%) and the difference in the thermal expansion coefficients of GaAs and Si result in high dislocation densities in the epitaxial GaAs. But if the sizes of active regions are drastically reduced, the number of dislocations in the active regions can also be reduced. Therefore, reliability can be expected to improve for the GaAs-based LEDs and lasers on $\mathrm{Si}$ with small active regions ${ }^{1}$. Further, for the lasers with small volume island like active region, the island density is an important factor ${ }^{2}$. For the low threshold current density of the laser, higher island density is required. Recently, we have introduced self-formed InGaAs islands grown by metal organic chemical vapor deposition (MOCVD) on GaAs substrate using Stransky-Krastanov (S-K) growth mode. The island density is found to be around $2 \times 10^{9} \mathrm{~cm}^{-2}$ with an average height of $20 \mathrm{~nm}$ and an average diameter of $50 \mathrm{~nm}$. It is expected that this island-like InGaAs active region will increase the reliability of the laser diodes on $\mathrm{Si}$ substrate.
\end{abstract}

Experiment : Samples were grown by MOCVD using S-K mode growth condition. Growths were done by changing the different growth parameters, such as, growth temperature, growth time, In-composition and $\mathrm{AsH}_{3}$ flow rate. After oxide desorption, a $2.5 \mu \mathrm{m}$ thick GaAs buffer layer was deposited upon the GaAs substrate at $650^{\circ} \mathrm{C}$, after which the substrate temperature was reduced to a lower value in order to deposit the desired amount of InxGal-xAs. The surface morphology of the samples were then observed with an Atomic Force Microscope (AFM).

Results and discussion : After a critical layer deposition of InGaAs, the surface transforms into three dimensional highly strained dot structures that grow coherently on the surface of GaAs. Figure 1 shows the AFM image of the InGaAs islands on GaAs substrate grown by MOCVD using S-K growth mode at $500^{\circ} \mathrm{C}$. The density of these islands is about $2 \times 10^{9} \mathrm{~cm}^{-2}$. The non uniformity in the island size is observed from the three dimensional image of fig. 1 . The size uniformity can be controlled by changing the InGaAs deposition time at a fixed growth temperature.

Conclusion : InGaAs islands on GaAs substrate have been realized by MOCVD using StranskyKrastanov (S-K) growth mode. It is expected that the high quality island-like InGaAs active region will stimulate to fabricate the reliable laser diodes on $\mathrm{Si}$ substrate.

1) T. Egawa, A. Ogawa, T. Jimbo and M. Umeno: Jpn. J. Appl. Phys. 37 (1998) 1552.

2) Z. I. Kazi, T. Egawa, T. Jimbo and M. Umeno: Jpn. J. Appl. Phys. 38 (1999) (to be published).

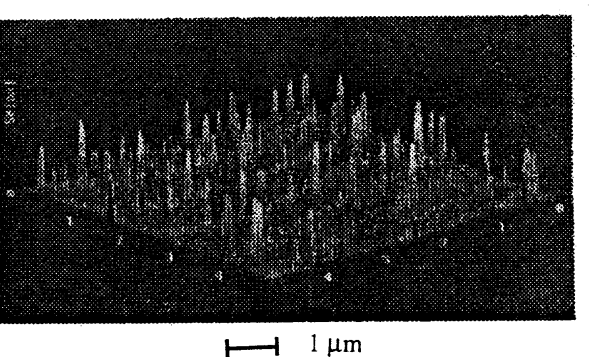

Figure 1: AFM image of the InGaAs islands on GaAs substrate grown by MOCVD using S-K growth mode at $500^{\circ} \mathrm{C}$.

\title{
$29 \mathrm{pVIII3}$ ポンププロープ法による多結晶CVDダイヤモンド薄膜の粒内キャリヤ寿命分布の锐測
}

Observation of decreasing of photo-generated carrier life time in CVD diamond film with fs-laser pump-probe method

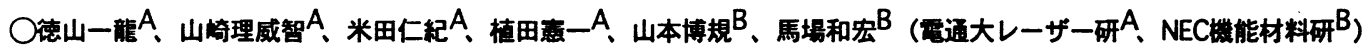

OK.Tokuyama ${ }^{A}$, R.Yamasaki ${ }^{A}$, H.Yoneda ${ }^{A}$, K.Ueda ${ }^{A}$, H.Yamamoto ${ }^{B},{ }$, K.Baba $^{B}$ (ILS,UEC ${ }^{A}$, Functional Materials Res. Lab. ${ }^{B}$ )

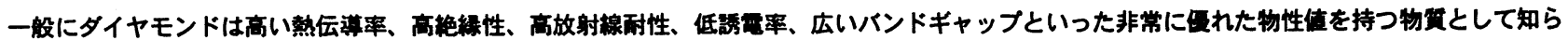
れており、特に近年の気相合成法 (CVD法) 技政の進歩により、不䢁物灙度の低いタイヤモンドを生成することが可能となってきた。しかし、CVDタ

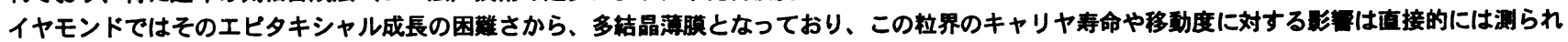

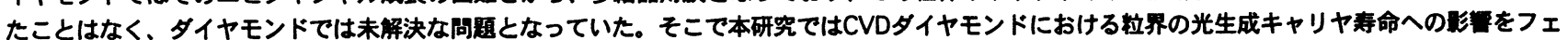

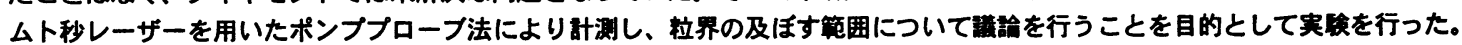

実呀方法としては、パルス幅100fsのAr+レーザー励起カーレンスモード同期Ti:Sapphireレーザーシステムの第 2 高調波（波長384nm）を用い、

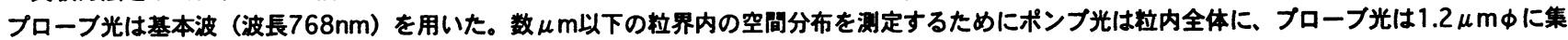
光し反射率测定を行なった。

右図は、その結果の一例であり、平均粒径4 $5 \mu \mathrm{m}$ 哈料中の入射レーザー光に 垂直な平面を持つ三角形状をしたグレインについて、その内部のキャリヤ友命分布 を测定したものである。横軸は三角形の一つの頂点から底辺に至る直楾上での竝内 キャリヤ寿命分布であり、柆界より $1 \mu \mathrm{m}$ 程度内部までキャリヤ寿命の低下が钼测 されていることが分かる。また、二つの粒界か影顬すると思われる三角形の頂点近傍 ては350fsという非常に短いキャリヤ寿命か钼测されたことから、別々の粒界の影需 がオーバーラップしている現象も钼測された。さらに、バンドギャップに比ベはるか。 に低い光子を用いたキャリヤ生成による反射瀫であることと、その寿命との相間 より、このような粒界近傍の影算はエネルキー蕉位そのものにも変化が起きている ことが示唆される結果となった。このような祥細のテータにより初めて柆界のキャリ ヤに対する影靁か钼測されたことで、今後、アニール等の後処理などによる粒界影整 の低減化などに有用なツールともなりうるであろう。

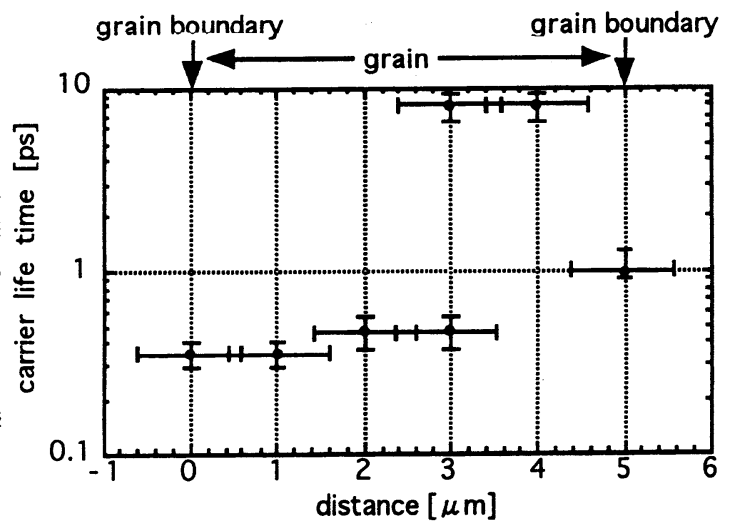


Study on damage of transparent conductive films by pulse laser irradiation.

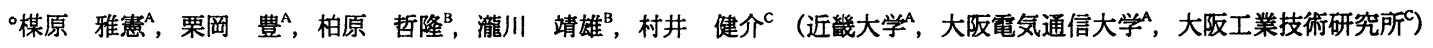

${ }^{\circ}$ M. Umehara ${ }^{A}$, Y. Kurioka ${ }^{A}$, A. Kashihara ${ }^{A}$, Y. Takigawa ${ }^{A}, K$. Murai ${ }^{c}$ (KINKI Univ. ${ }^{A}$, OECU $^{A}$, Osaka National Research Institute ${ }^{c}$ )

透明導電膜は、液晶ティスプレイ（L C D ）などフラットパネルティスプレイ（F P D）の電 極用材料として広く使われている。通常の透明導電膜は、高い透過率と低い抵抗率をあわせもつ ものであって、酸化インジウムや酸化スズなどの金属酸化物や非常に薄くした金属薄膜がある。 特に、スズを $5 \sim 10 \%$ ドープした酸化インジウム（ITO ; Indium Tin Oxide)は、 $10^{-4} \Omega \cdot c$ $\mathrm{m}$ という低い抵抗率とエッチングの容易さから最も使われている透明導電材料である。I T O は、 $10{ }^{19} \mathrm{~cm}^{-3}$ 以上の電子キャリア密度をもち、3，5 $\mathrm{eV}$ 以上のバンドギャップをもつため、赤 外波長域と紫外波長域では透明ではないが、可視波長域では透明である。

近年、レーザー装置の共振器内に液晶素子を導入し、パルスレーザーを電気的に制御することに より空間変調したレーザー装置の開発が期待されている。これが実現すれば、機械的駆動部のな い画像発振可能なレーザー装置が実現可能となるため、レーザーディスプレイやレーザー加工機 などへの実用化が期待できる。しかし、透明導電膜は、他の光学部品と比較してレーザー損傷し きい值が低く、このようなレーザー装置の開発が遅れている。これは、透明導電膜のもつ高い電 子密度のためにレーザー光が吸収され膜が加熱された結果と推測されている。図は、レーザー椇 傷した I T O薄膜である。ガラス基板上に電子ビーム蒸着法で成膜した膜厚約 $200 \mathrm{~nm}$ の I T O 膜に、YAGレーザー（波長 $1[\mu \mathrm{m}]$ 、パルス幅 $8[\mathrm{~ns}] 、$ 照射強度約 $2\left[\mathrm{~J} / \mathrm{cm}^{2}\right]$ ）を照射した。未照 射部と比較して、損僨部は黒く変色した。このことから、損傷部は組成が変化したものと考えら れる。

我々は、高強度レーザー装置に搭載可能な高レーザー耐力の透明導電膜を開発するために、レ ーザー損傷部の構造や組成について評価した。講演では、透明導電膜のレーザー損傷部の総合的 な評価について報告する。

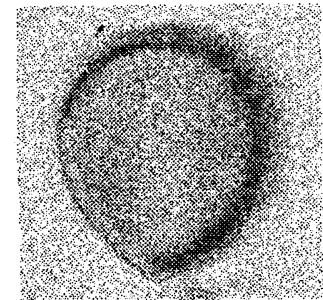

図 I T O薄膜のレーザー損傷部（中央部）

\section{$29 \mathrm{pVIII5}$ 表面化学反応により形成された $\mathrm{TiO}_{2}$ 薄膜の評価}

Characterization of $\mathrm{TiO} 2$ thin films grown with surface chemical reaction

・財津慎一、本越伸二^、實野孝久、山中龍彦 （阪大レーザー研、レーザー総研^）

Shin-ichi Zaitsu, Shinji Motokoshi^, Takahisa Jitsuno, Tatsuhiko Yamanaka (ILE Osaka Univ., Inst. Laser Technol.^)

\section{はじめに}

我々は原料カスを交互に導入し、基板表面での化学反応により酸化物光学薄膜を形成してきた。この成膜法は膜厚の優れた制御性と均一性を有し ており、慣性核融合等で用いられるレーザー用高性能光学薄膜の形成法としての応用が期待できる。高出力、大口径レーザーシステムで用いられる 光学薄膜においては広範囲に亘る膜厚の均一性と高いレーザー損傷耐力が要求されている。表面化学反応によって形成された光学薄膜では大面積基 板への均一成膜は可能であるが、レーザー損傷耐力に関しては十分な性能が得られていない”。そこで本研究ではTiCl4とH2Oの表面化学反応によっ て形成したTiO2薄膜の構造、組成を分析するとともに、微少光吸収を評価することでレーザー損傷しきい値を決定する要因を解明し、レーザー損傷 耐力の向上への方策を得ることを目指した。

結果

形成された薄膜のレーザー損傷耐力は成膜温度に依存し、低温で成膜した方が比較的高いレーザー耐力を有す る。この依存性の原因を明らかにするためにXRDによる結晶性の評価とSEMによる構造観察を行った。XRD分析

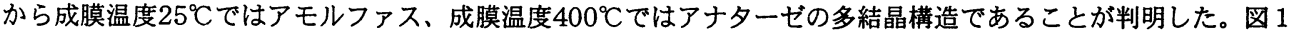

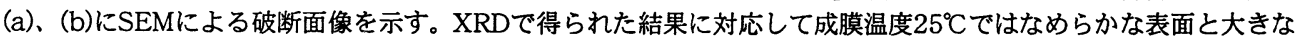

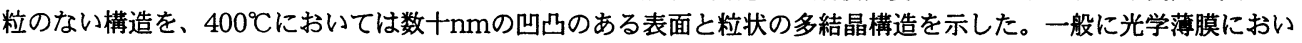
てはアモルファス構造の方が光学特性が良く、レーザー損偒耐力も高い。従って、この結果はレーザー損傷耐力の 成膜温度依存性と一致する。また、SIMSによる組成分析では、低温で成膜した際に膜中のCl強度の增加が見られ た。このClは低温においてTiCl4とH2Oの化学反応時に完全に反応せずに表面に残ったものであると考えられる。 膜中に存在するClとレーザー損傷耐力の関係は明らかでない。光音響法 (PAS) を用いたTiO2薄膜の $1 \mu \mathrm{m}$ 光の吸収 量測定においては、成膜温度の上昇に伴って膜中の吸収量も増加し、レーザー損傷耐力が光吸収量の增加に伴って 低下していることが判った。今後は、残留Clの量と光吸収の関係、およびレーザー損傷耐力との関連性について調 査していく。

1) S. Zaitsu, S. Motokoshi, T. Jitsuno, T. Yamanaka, to be published in Proceedings of 3th Annual International Conference on Solid State Lasers for Application to Inertial Confinement Fusion, Proc. of SPIE.

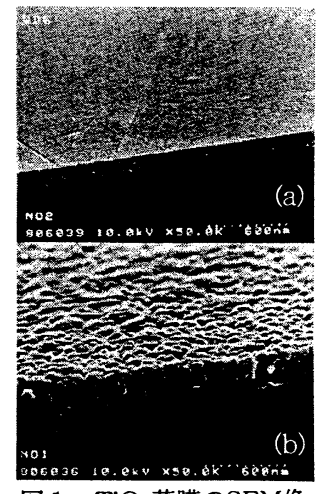

図 1. TiO2薄膜のSEM像 $\begin{array}{ll}\text { (a) } 25^{\circ} \mathrm{C} & \text { (b) } 400^{\circ} \mathrm{C}\end{array}$ 
Ti diffused waveguide lasers on Nd-diffused Z-cut $\mathrm{LiNbO}_{3}$ ヤンキムシン 藤村 昌寿 井上揵 津川 英信 ○西原 浩 (阪大院工)

K.S. Yang,M. Fujimura, T. Inove,H. Tsugawa and H.Nishihara (Grad. School Eng., Osaka Univ.)

我々はNd 熱拡散 LiNbO,(LN)導波路レーザーとその高機能化の研究をしている[1]。高機能化のためには、TE/TM 両モードが導波可能で、最大電気光 学定数 $r_{33}$ が利用可能な、Z 板 $T i$ 拡散 $L N$ 導波路レーザーが有利である。しかし、Z 板 Ti 拡散導波路では光損傷の問題のため、パルス発振の報告しか なかった[2]。本研究では、LNに比べて光損䅞耐性の高いMgO 添加 LNに Nd 熱拡散によりドープした基板を用いて光導波路レーザーを作製すること を検討し、Z板 Ti 拡散 Nd : LN 導波路レーザーの連続発振を達成した。

図 1 に導波路レーザーの構成を示す。Nd 熱拡散 Z 板 MgO : LN 基板上で、チャネル Ti 拡散導波路とその両端面に装荷した誘電体多層膜ミラーでレー ザー共振器を構成している。Nd の吸収ピークである波長 809nm(TE モード)の導波光で励起すると、波長 $1085 \mathrm{~nm}$ の TM モードレーザー光が得られる。

予備実験として Z 板 Nd 熱拡散 MgO : LN 上での Ti 拡散導波路の作製を試みた。通常の LN に比べて Nd 熱拡散 MgO : LN ではTi が拡散しにくいことが分

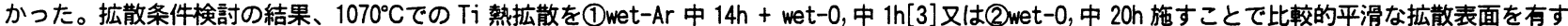
る低損失な Ti 拡散導波路を得た。ただし、(1)では顕著な $L i, 0$ 外拡散が見られた。(1)、(2)で得られた拡散表面の顕微鏡拡大写真を図 2 に示す。

(1)と(2)の条件でそれぞれ導波路レーザー(S1 とS2)を試作した。Nd熱拡散では、約 $10 \mu \mathrm{m}$ 厚の Nd 膜を Z 板 MgO : LN に乾燥 0, 中で $1070^{\circ} \mathrm{C} 、 300$ 時間捬 散した。次に、 $10 \mu \mathrm{m}$ 幅、約 $70 \mathrm{~nm}$ 厚の Ti ストライフを熱㧨散して Ti 拡散導波路を作製した後、その両端面を研碞、誘電体多屏膜ミラーを光学的密着 によって装荷して導波路共振器を得た。ミラーの反射率は発振波長に対して98\%、励起光に対して6\%であった。

$\mathrm{Ti}: \mathrm{Al}_{2} \mathrm{O}_{3}$ レーザーを励起光源として用い、S1、S2 のレーザー発振を試みた。波長 809nm の TE モード導波光(常光線)で励起すると、S1、S2 ともに波 長 $1085 \mathrm{~nm}$ の TM モードレーザー光の連続発振が得られた。図3に出カレーザー光パワーの吸収励起光パワー依存性を示す。闘值パワーは $S 1$ が $62 \mathrm{~mW} 、$

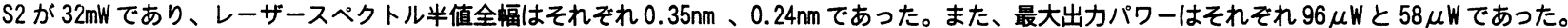

波長 $814 \mathrm{~nm}$ の TM モード導波光(異常光線)励起でのレーザー発振も試みた。S2においてのみ波長 $1085 \mathrm{~nm}$ の連続レーザー発掁が確認できた。闘值パワ 一は32mWであった。S1では顕著な光損偒が生し、安定な連続レーザー発振は得られなかった。

以上のようにZ 板 Nd 熱拡散 MgO:LNの Ti 拡散導波路レーザーの連続発振が得られた。しかし、Ti 拡散条件はまだ分に確立されたとは言えない。 今後、Ti 拡散条件の最適化により、低闇値、高効率なレーザー発振を実現したい。

文献 : [1]藤村, レーザー学会講演予定(1999.1).[2]R.Brinkmann et al., IEEE Quantum Electron., 28 , 466, 1992. [3]藤村他, 平 9 秋応物, 3p-ZB-11,1997. 榭辞 : 貴重な助言を頂く本学医学部教授春名正光先生に感謝 します。Nd 熱 拡散に御協力 頂く、三菱電線 須藤氏、寺澤氏 Pump に感謝します。

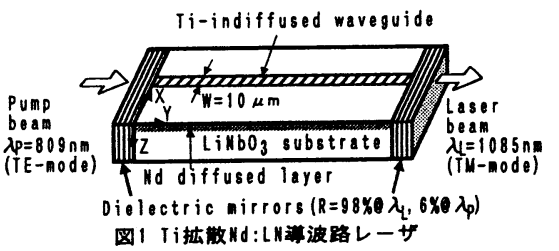

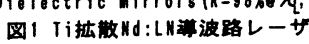

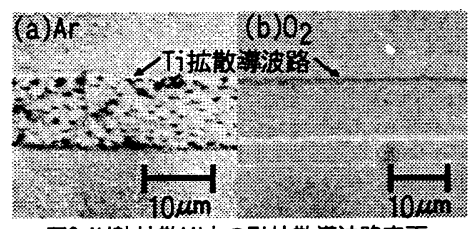

図2 Nd熱拡散LN上のTi拡散筫波路表面

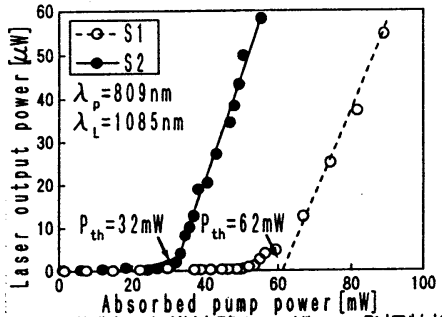

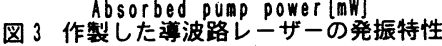

$29 p$ VIII8

液相エピタキシャル成長 $\mathrm{LiNbO}_{3}$ 薄膜による QPM-SHG デバイスの作製

Fabrication of $\mathrm{LiNbO}_{3}$ thin-film QPM-SHG devices by liquid phase epitaxy

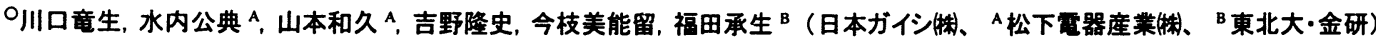

${ }^{\circ}$ T. Kawaguchi, K. Mizuuchi ${ }^{A}$, K. Yamamoto ${ }^{A}$, T. Yoshino, M. Imaeda, T. Fukuda ${ }^{B}$

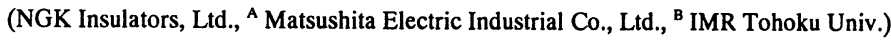

はじめに）液相エピタキシャル(LPE) 法によるLN単結晶薄膜は、バルク単結晶では困難な化学量論組成 の高品質膜が得られ、ドーピングが容易、ステップ届折率樓造をもつ多層膜形成が可能等の優れた特徵 を有し、光導波路デべイス基板として、また新しい光道波路形成法として期待されており、我々は算波 路型QPM-SHGデバイスへの応用を検討中である. 今回LPE-LN技街のSHGデパイスへの応用例として、 膜成長時の分極反転現象を利用した新しい周期分梗反転形成プロセス、およひ酎光損伤特性の向上に

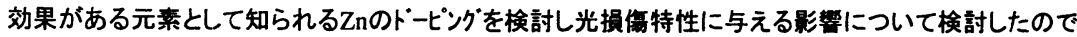
報告する。

成膜方法） $\mathrm{Li}_{2} \mathrm{O}-\mathrm{V}_{2} \mathrm{O}_{5}$ をフラックスするメルトから市販のZ仆あるいはXか外のLNまたは5 $\mathrm{mol} \% \mathrm{Mg}$ トープ

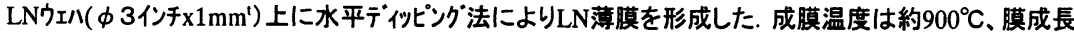
速度は $1 \mu \mathrm{m} / \mathrm{min}$ 程度で、鏡面状のIピタキジル膜が得られた。

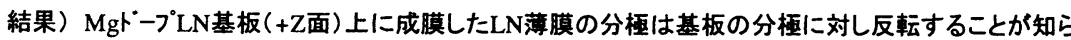

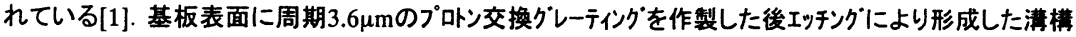
造部に分極反転LN薄膜を成長させることにより周期分梗反転権造を作製した(図1)[2]。作製した QPM-SHG素子を評価した結果、波長約440nmのSHG出カが得られた.

また、Znドープによる酎光損偒効果を調べるため、X加基板上に約 $8 \mathrm{~mol} \%$ のnドープLN薄膜を形成し た後、横方向電圧印加法により周期反転形成し(図2)、QPM-SHG秦子を作製しSHG特性を評価した 結果、ハドープ膜では出力数 $10 \mu \mathrm{W}$ 程度で光損侮が発生するのに対してZnドープ膜では出カ3mW以上 においても光損繋が見られず酎光損傷特性が大幅に向上することを確認した[3].

[1] A. Yamada et al., J. Crystal Growth 132 (1993) 48. [2]川口他; 1996秋季応物学会予稿集9p-ZE-14 [3]川口他; 1998秋季応物学会予稿集15p-T-3

周期状溝加工

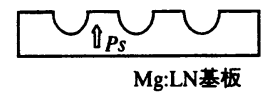

凸

反転LPE成膜

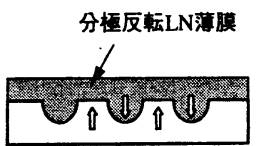

図1 分梗反転LPEIよる周期分極反転構造 の作製（Z加基板）

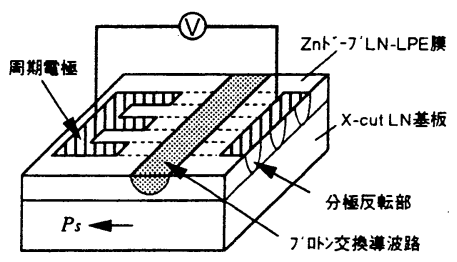

図2 Znド-プLPE-LN膜によるQPM-SHG素子 の作嫳(X力仆基板) 


\section{9p v⿴囗十Ｅｒ含有結晶における負性非線形吸収効果}

Negative Nonlinear Absorption Effect in erbium-included crystals

○山田寿一、秋月義樹”、桑野泰彦”、前田佳伸”（中国工業技術研究所、豊田工業大学工学部”、NEC 機能材料研究所“）

${ }^{\circ}$ T. Yamada, Y. Akidzuki, Y. Kuwano and Y. Maeda (CNIRI, Toyota Tech. Inst. ', NEC"*)

はじめに 近年、Er:YAG（Erbium doped Yttrium Aluminum Garnet）結晶において、負性非線形吸収効果（Negative Nonlinear Absorption（NNA）effect ; i.e. Maeda effect）が発現することが見い出された。この現象は光学材料に強度変調をかけたレーザー光（800nm 付近）を透過させたときに起きる が、簡単に言うと入射レーザー光が増加した時の透過光の強度が、入射レーザー光が隇少している時の透過光の強度よりもかえって弱いという奇妙 な逆転現象である（図参照: 下のグラフは入射光の強度変化を示し、上のグラフは透過光の強度変化を示す。透過光の強度変化の絶対值は入射光よ りも低いので、グラフでは拡大している)。この現象は YAG 結晶中の $\mathrm{Er}^{3+}$ のエネルギ一準位構造における多準位系の励起吸収を利用したものであり、 特徵として、低い光強度 $\left(60 \mathrm{nW} / \mathrm{cm}^{2} \sim 100 \mathrm{~W} / \mathrm{cm}^{2}\right)$ で生じること、および負性の光入出力特性を有し、NOT 形の全光形スイッチング素子を構築でき

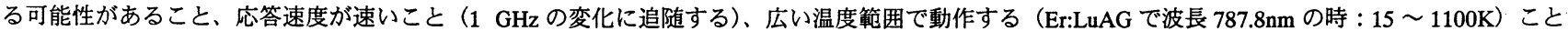

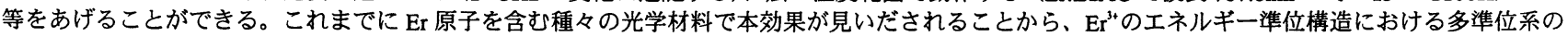
励起吸収が原因であると推測している。レート方程式からのシミュレーションも同時に行っているが、本効果を支持するものとなっている。今回、 本効果が光学結晶中の $\mathrm{Er}$ 濃度にどのように依存するかを調べるために、 Er 含有率が $30 、 50 、 75 、 100 \%$ 種類の結晶を用意した。その結 果、結晶中の $\mathrm{Er}$ 濃度に依存していることが明らかとなったのでこれを報告する。本効果では入射光の吸収過程が $2 つ$ 存在するが、励起準位にある電 子が再び励起されることが重要であることを同時に説明する。

実験と結果 単一モードの GaAlAs 半導体レーザーを用い、直接レーザードライバを変調することによ つてパルス波の光量变調光を得た。レーザーヘッド温度を制御することによって発振波長（788nm 近 辺）を一定に制御し、光スペクトロアナライザを用いて単一モード発振であることを確認しながら実 験を行った。実験に用いた試料は、YAG 結晶の Y をそれぞれ、一定程度 Er に置換した結晶であり、Er 含有率が $30 、 50 、 75 、 100 \%$ 種類である。レーザーの入射光および試料の透過光をフォ トダイオードで検出してオシロスコーブで観察した。それぞれの結晶において試料長を変えて試料の レーザー光透過特性を調べた。その結果、それぞれの試料で試料長が長くなるに従って、反転現象が 度 強く出ることを確認した。特に Er 濃度と試料長との積算が一致する場合には、ほぼ同様のレーザー光 透過特性を示したことから、NNA 効果が試料中の Er 含有量に依存していると考えられる。

参考文献 (1) Enhanced absorption by stimulated emission in three excited states of $\mathrm{Er}^{3 *}$ in Yttrium aluminum garnet: Y. Maeda and M. Migitaka, Appl. Phys. Lett., Vol. 70, pp. 4-6 (1997)

(2) Temperature dependence of the enhanced excited state absorption in erbium-doped garnets:Y. Maeda and $\mathrm{T}$.

Yamada, J. Appl. Phys., Vol. 83, pp. 7436-7441 (1998).

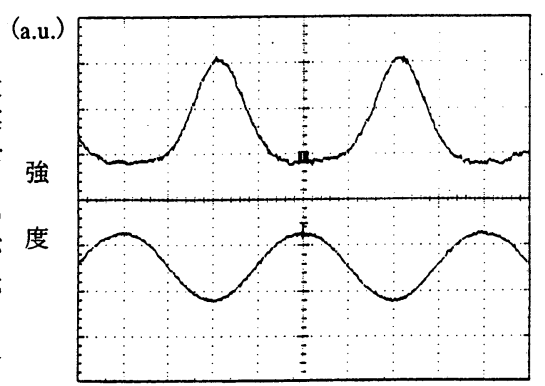

入射光強度と透過光強度の時間変化 （変調周波数 $1 \mathrm{MHz} 、 \mathrm{Er}$ 含有率 $75 \%$ ）

$29 \mathrm{pVVIII10}$

\section{$\mathrm{KB} \mathrm{r}$ 基板上に作製されたV O P c 単結晶の成長機構}

Growth mechanism of VOPc Single Crystal Prepared on $\mathrm{KBr}$ substrate

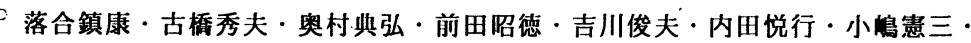
大橋朝夫・家田正之（愛知工業大学）

S. Ochiai, H. Furuhashi, N. Okumura, A. Naeda, T. Yoshikawa, Y. Uchida,

K. Kojima, A. Ohashi, M. Ieda (Aichi Inst., Tech.)

1.まえがき 光素子として, バナシルフタロシアニン（VOPc）単結晶が注目され ている, 光学テバイスへの応用を考えると, 位相整合条件が成り立ては，非線形光学 材料へのレーザ光入力に対する出力の二次 $(\mathrm{SH})$, 三次高調波 $(\mathrm{TH})$ 発生が膜厚の二乗に 比例することから，エピタキシー，単斜晶成長した大きなVOPc単結晶を作製すること が重要である,

2. 試料と実験方法 試料としては, VOPc粉末を用いた, VOPc単結晶の作製には，

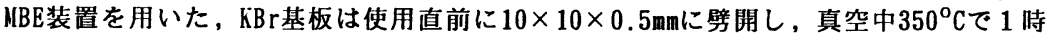
間予備加熱を行なった, 蒸着条件は蒸発源温度 : $300^{\circ} \mathrm{C}$, 基板温度: $\mathrm{Ts} ; 200^{\circ} \mathrm{C}$, 蒸着

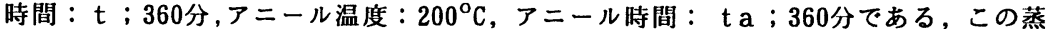
着条件で作製されたVOPc単結晶の獏厚が $\mathrm{d}: 0.19 \mu \mathrm{m}$ になる, 単結晶の構造については, SEN,UV/VISスペクトル,RHEEDを用いて解析した。VOPc単結晶の非線形光学性については， メーカーフリンジ法を用いて解析した。

3. 実験結果の検討 図 1 は所定の蒸着条件で作整されたVOPc単結昌のSEM像を示す,

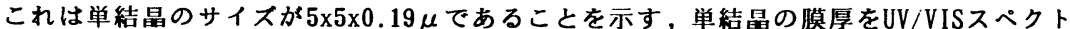
ルから見積もった，単結晶の構造については，UV/VISスペクトルの780 $\mathrm{nm}$ で吸収ピークを もつこと, RHEEDで観察された輝線より見積もられたa軸の面隔が単斜晶に一致すること から，単結晶が単斜晶からなる結晶であることを示睃した。単結晶の成長については， 最初に，微結晶が高温基板上を移動し，合併することにより，結晶が成長する。つぎの 段階で，成長した単結晶が合併することにより，単結晶の成長がさらに進む，さらにつ ぎの段階で，単結晶の侧面が擬結晶を合併することにより，図 1 に示す大形の単結晶が 成長したと考えることができる。メーカーフリンシ・法によるVOPc単結晶の三次非線形光 学強度の测定結果から, 三次非線形光学感受率 $\chi^{(3)}$ を見積もった。 その $\chi^{(3)}$ 值は $1.3 \times 10^{-9} \mathrm{e} \mathrm{su}$ になる。この值は最近Fang等により報告された值の約5倍になる。この ことは各種光テバイス作製に重要な意味をもつことを示す。

参考文献 S. Fang, H. Tada and S.Mashiko,Appl. Phys. Lett., 69, 767 (1996)

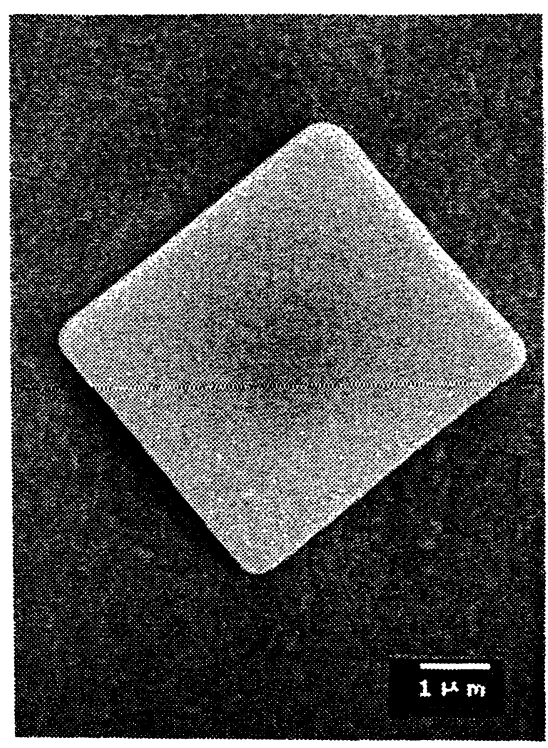

図 1 VOPc単結晶のSEN像 